\title{
Development of a Supercritical Fluid Extraction Method for Simultaneous Determination of Organophosphorus, Organohalogen, Organonitrogen and Pyretroids Pesticides in Fruit and Vegetables and its Comparison with a Conventional Method by GC-ECD and GC-MS
}

\author{
Sandra Regina Rissato ${ }^{*, a}$, Mário Sérgio Galhiane ${ }^{a}$, Antonio G. de Souza ${ }^{b}$ and Bernhard M. Apon ${ }^{c}$ \\ ${ }^{a}$ Departamento de Química, Universidade Estadual Paulista, Av. Luiz Edmundo Carrijo Coube $s / n^{\circ}$, \\ 17033-360 Bauru - SP, Brazil \\ ${ }^{b}$ Departamento de Química, Universidade Federal da Paraíba, 58059-900 João Pessoa -PB, Brazil \\ ${ }^{c}$ Chromapon Inc. 9815 Carmenite Road, Suite J., 90605 Whittier - CA, USA
}

\begin{abstract}
O presente trabalho tem como objetivo aplicar uma metodologia multiresíduo visando a determinação de pesticidas em frutas e vegetais, utilizando extração com fluido supercrítico e análise por cromatografia gasosa e detector por captura de elétrons e espectrometria de massas. Um método convencional por extração sólido-líquido baseado na literatura e um método com fluido supercrítico desenvolvido, foram aplicados na determinação simultânea de 32 pesticidas de 4 classes diferentes (organoclorados, organonitrogenados, organofosforados e piretróides) em amostras de alface, batata, maçã e tomate. As recuperações obtidas para a maioria dos pesticidas foram de $74 \%$ a $96 \%$ para ambos os métodos em níveis entre $0,04-0,10 \mathrm{mg} \mathrm{kg}^{-1}$, os limites de quantificação (dependendo da matriz e do pesticida) foram menores que $0,01 \mathrm{mg} \mathrm{kg}^{-1}$. SFE mostrou-se vantajosa quando comparada à extração sólido-líquido como economia de solventes, tempo e custos, podendo ser aplicada no monitoramento de pesticidas em alimentos.
\end{abstract}

The aim of this paper was to apply a multiresidue method using Supercritical Fluid Extraction (SFE) and capillary gas chromatography with electron capture and mass spectrometry detections in the analysis of the levels of pesticide residues in fruits and vegetables. Single laboratory validation of both solid-liquid and supercritical fluid extraction methods was carried out for 32 compounds selected from four pesticide classes (organochlorine, organonitrogen, organophosphorus and pyretroid) in blank and fortified samples of fresh lettuce, potato, apple and tomato. Recoveries for the majority of pesticides from fortified samples at fortification level of $0.04-0.10 \mathrm{mg} \mathrm{kg}^{-1}$ ranged 74$96 \%$ for both methods and confirmation of pesticide identity was performed by gas-chromatographymass spectrometry in a selected-ion monitoring mode. Both methods showed good limits of detection (less $0.01 \mathrm{mg} \mathrm{kg}^{-1}$, depending on the pesticide and matrix) and the SFE method minimized environmental concerns, time, and laboratory work.

Keywords: pesticides multiresidue analysis, supercritical fluid extraction, fruits, vegetables

\section{Introduction}

Pesticides are necessary and essential in agricultural production. Increasing public concern, in recent years, about health risks from pesticide residues in the diet, has led to strict regulation of maximum residue limits (MRL) and total dietary intake of pesticide residues in foodstuffs. ${ }^{1}$ In an effort to monitor the levels of these residues, many governmental and industrial programs have been implemented for the regulatory analysis of pesticide

*e-mail: srissato@fc.unesp.br residues in food through multiresidue methods. Standard multiresidue procedures for fruit and vegetables are described by many monitoring agencies, in their screening programs ${ }^{2}$ and are officially accepted in many countries.

The analysis of trace levels of pesticides in food, frequently requires the removal of high molecular weight interferences such as lipids and natural resins before the analysis by gas chromatography or high performance liquid chromatography. ${ }^{3}$ The extraction process is the first and a major limiting step in the pesticide residue analysis, often involving sample preparation such as chopping and maceration, followed by solvent extraction. The 
conventional methods often involve laborious blending and vigorous processes, which are time consuming and involve large volumes of hazardous solvents. In recent years, the analysis of pesticide residues in food has incorporated new technologies to develop and use procedures, which minimize environmental concern, time, labor, and exposure of laboratory technicians to toxic chemicals. $^{3,4}$

Sample preparation methods, generally used by analytical chemists, are both time and solvent consuming. According to a recent survey, two thirds of the analysis time is devoted to sample preparation and this step accounts for at least one third of the error generated during the performance of an analytical method. ${ }^{1}$ Recent concerns about the hazards associated with most of the solvents used, and the costs and environmental dangers of solvent waste disposal, have led to the development of alternative sample extraction methods such as solid-phase extraction (SPE) and supercritical fluid extraction (SFE). ${ }^{5}$

SFE has gained increased attention as a potential replacement for conventional liquid solvent extraction (sonification or Soxhlet) owing to the properties of supercritical fluids: high diffusivity and low viscosity. The greatest advantage of supercritical fluids, however, is the fact that they have densities (and solvating powers) comparable to the density of liquids, which can be continuously varied by one order of magnitude by varying the temperature and pressure of the extraction vessel. ${ }^{6}$

Supercritical fluid extraction (SFE) is an alternative to the solvent-intensive isolation procedures, especially for environmental samples. In the area of agrochemicals, SFE has been used for selective extractions of organophosphorus and organochlorine pesticides, ${ }^{7-9}$ carbamates ${ }^{10,11}$ and different herbicides, ${ }^{12,13}$ from different matrices.

$\mathrm{CO}_{2}$ is frequently used as a supercritical fluid due to its suitable critical temperature $\left(31.2{ }^{\circ} \mathrm{C}\right)$ and pressure $(72.8$ atm), since it can be easily removed by reducing its pressure. $\mathrm{A} \mathrm{CO}_{2}$ density of $0.8-0.9 \mathrm{~g} \mathrm{~mL}^{-1}$ appears to be adequate for most pesticides. ${ }^{14}$

Satisfactory extraction efficiencies were reported for non-polar to low polar pesticides such as organochlorine ${ }^{15}$ and organophosphorus. ${ }^{16}$ For pesticides of high polarity and metabolites of pesticides, the addition of polar modifiers such as methanol or water to $\mathrm{CO}_{2}$, enhances its dissolving power. For meat and fatty material, the separation of lipids from lipophilic pesticides is essential for accurate analysis. ${ }^{17,18}$

Multiresidue methods were firstly developed to improve the cost-effectiveness without sacrificing the reliability of the results. The presence of matrix interferences in extracts of fresh fruit and vegetables adversely affect analyte quantification and identification. Clean-up is necessary in order to reduce the detection limits of methods and/or to avoid interferences from the matrix. Sample clean-up techniques include gel permeation chromatography, ${ }^{19}$ liquid-liquid partitioning using various solvents, ${ }^{20}$ solid phase extraction (SPE), adsorption chromatography (on silica, Florisil, active carbon, alumina) and membrane technologies..$^{21,22}$

Chromatographic methods are the most suitable ones for residue analysis, in particular, gas chromatography (GC) using long, narrow-bore capillary columns equipped with selective and sensitive detection methods such as electroncapture detection (ECD), nitrogen-phosphorus detection (NPD) and flame-photometric detection (FPD) according to different classes of pesticides. The identification and separation by GC can be increased when combined with confirmation capabilities of mass spectrometry (MS). Mass spectrometry is a very sensitive and selective technique for both multiresidue determination and trace level identification over a wide range of pesticides. ${ }^{23,24}$

The aim of the present work was to apply a rapid and accurate multiresidue method, to determine organohalogen, organonitrogen, organophosphorus and pyretroid pesticides in routine testing of fruit and vegetables entering local markets.

This study describes two different methods of extraction: one, using acetone by solid-liquid extraction and another by SFE (testing many extraction conditions) for multiresidue analysis of pesticides. Clean-up was based on aminopropyl cartridge extraction, followed by GC/ECD for determination, and the confirmatory analysis was carried out by GC/MS in the selected-ion monitoring (SIM) mode. The extraction efficiencies were directly compared to those achieved using Solid Liquid Extraction (SLE). After this point, the methods were applied to the analysis of real samples and the results were discussed.

\section{Experimental}

Samples

The studied samples, potatoes, tomatoes, apples and lettuce were purchased at a local supermarket. The pesticides chosen were those most used in our region. For fortification studies, pesticides free matrices, deriving from a special field cultivated with no pesticides (organic) were used. Fruit and vegetables were processed as specified in the European Union Legislation. ${ }^{25}$ Circa $500 \mathrm{~g}$ of crop sample was washed with water and chopped, blended for 3-5 min using a blender equipped with a stainless steel 
cutting unit, a glass jar, weighed and submitted to extraction.

\section{Reagents, solvents and reference pesticide standards}

Pesticide reference standards were purchased from Dr. Ehrenstorfer (Augsburg, Germany) with purity ranging from 95-100\%. The pesticides investigated are listed in Table 1. Pesticide stock solutions (approximately $500 \mathrm{mg} \mathrm{L}^{-1}$ ) of individual pesticide standards were prepared by dissolving approximately $0.050 \mathrm{~g}$ of the pesticide in $100 \mathrm{~mL}$ of acetone:n-hexane (50:50, v/v) and stored in freezer under $-18{ }^{\circ} \mathrm{C}$ in glass bottles with PTFE- faced screw caps. Pesticide working solutions were prepared for recovery tests by solid-liquid and SFE methods by appropriate dilution of acetone:n-hexane (50:50, v/v).
Acetone, acetonitrile, n-hexane, dichloromethane, ethyl acetate and methanol, of a special grade for pesticide residue analysis were purchased from Mallinkrodt, Merck. Sep-Pak Vac aminopropyl cartridges ( $3 \mathrm{~mL}, 500 \mathrm{mg}$ ) were purchased from Waters (Milford, MA). A special siphonated $\mathrm{CO}_{2}$ from White Martins was also used in SFE.

\section{Extraction procedure}

The solid-liquid extraction method used in the determination of multiresidue was based on the literature with some modifications. ${ }^{26}$ A 25 g portion of the homogenated crop sample was weighed in a $250 \mathrm{~mL}$ beaker and fortified when required with the pesticides standard solution. After a $15 \mathrm{~min}$ equilibrium period, $40 \mathrm{~g}$ of hydromatrix were added to the beaker and the sample was

Table 1. Retention times, recoveries (RSD\%, $\mathrm{n}=5$ ) and detection limits of pesticides in the matrices studied, obtained by solid-liquid extraction and GC/ECD

\begin{tabular}{|c|c|c|c|c|c|c|c|}
\hline \multirow[t]{2}{*}{ Pesticides } & \multirow[t]{2}{*}{$\mathrm{t}_{\mathrm{R}}(\min )$} & \multirow{2}{*}{$\begin{array}{c}\text { Fortification } \\
\text { Level }\left(\mathrm{mg} \mathrm{kg}^{-1}\right)\end{array}$} & \multicolumn{4}{|c|}{ Recovery (RSD\%) } & \multirow[t]{2}{*}{ LOD $\left(\mathrm{mg} \mathrm{kg}^{-1}\right)$} \\
\hline & & & Apple & Lettuce & Potato & Tomato & \\
\hline 1- Dichlorvos & 7.27 & 0.05 & $66(4.9)$ & $71(6.5)$ & $69(5.6)$ & $66(6.4)$ & 0.007 \\
\hline 2- Linuron & 8.84 & 0.07 & $75(5.8)$ & $76(4.7)$ & $80(8.1)$ & $77(5.9)$ & 0.005 \\
\hline 3- Trifluralin & 17.30 & 0.05 & $83(6.3)$ & $82(6.6)$ & $81(5.0)$ & $81(5.1)$ & 0.002 \\
\hline 4- Hexachlorobenzene & 21.11 & 0.07 & $85(6.8)$ & $80(8.7)$ & $82(6.1)$ & $83(4.6)$ & 0.002 \\
\hline 5- Dicloran & 23.50 & 0.05 & $74(4.9)$ & $76(6.1)$ & $78(7.3)$ & $79(6.5)$ & 0.002 \\
\hline 6- Diazinon & 24.08 & 0.07 & $85(8.3)$ & $83(8.1)$ & $82(7.4)$ & $83(7.6)$ & 0.005 \\
\hline 7- Dimethoate & 25.16 & 0.05 & $69(5.3)$ & $65(6.8)$ & $64(5.9)$ & $66(6.0)$ & 0.006 \\
\hline 8- Chlorothalonil & 26.47 & 0.05 & 65 (6.6.) & $70(5.8)$ & $66(6.8)$ & $68(7.1)$ & 0.001 \\
\hline 9- Vinclozolin & 26.57 & 0.07 & $74(6.9)$ & $77(6.4)$ & $76(7.2)$ & $79(5.5)$ & 0.002 \\
\hline 10- Aldrin & 27.99 & 0.10 & $77(7.1)$ & $73(6.8)$ & $71(5.9)$ & $73(7.4)$ & 0.002 \\
\hline 11- Metolachlor & 28.87 & 0.05 & $78(5.5)$ & $75(7.2)$ & $79(4.6)$ & $81(6.3)$ & 0.005 \\
\hline 12- Triadimefon & 29.17 & 0.06 & $80(5.8)$ & $79(6.9)$ & $82(6.9)$ & $83(5.4)$ & 0.002 \\
\hline 13-Chlorpyrifos & 29.53 & 0.06 & $81(5.2)$ & $77(5.6)$ & $82(6.9)$ & $83(7.1)$ & 0.001 \\
\hline 14- Dicofol & 30.03 & 0.05 & $80(5.3)$ & $76(6.4)$ & $82(5.6)$ & $81(3.8)$ & 0.005 \\
\hline 15- Triadimenol & 31.28 & 0.06 & $77(7.7)$ & $75(8.2)$ & $79(5.3)$ & $80(6.7)$ & 0.008 \\
\hline 16- Endosulfan Alfa & 32.50 & 0.05 & $83(3.8)$ & $74(5.9)$ & $81(6.6)$ & $84(7.3)$ & 0.001 \\
\hline 17- Hexaconazole & 33.27 & 0.05 & $85(5.4)$ & $82(6.3)$ & $83(4.8)$ & $81(4.5)$ & 0.003 \\
\hline 18- Imazalil & 33.90 & 0.05 & $81(3.6)$ & $80(4.2)$ & $84(5.8)$ & $82(3.3)$ & 0.004 \\
\hline 19- Buprofezin & 34.96 & 0.05 & $81(8.3)$ & $79(6.7)$ & $80(5.5)$ & $83(7.0)$ & 0.005 \\
\hline 20- Endosulfan Beta & 36.41 & 0.06 & $77(5.0)$ & $75(4.6)$ & $79(6.2)$ & $81(6.2)$ & 0.001 \\
\hline 21- Etaconazole & 36.55 & 0.06 & $80(5.7)$ & $77(7.0)$ & $79(3.8)$ & $78(5.6)$ & 0.002 \\
\hline 22- Propiconazole & 37.73 & 0.05 & $78(7.3)$ & $77(7.1)$ & $80(6.8)$ & $81(6.9)$ & 0.002 \\
\hline 23- Tebuconazole & 38.41 & 0.05 & $83(8.2)$ & $80(5.9)$ & $82(7.2)$ & $84(6.6)$ & 0.006 \\
\hline 24- Diclofop-methyl & 38.65 & 0.08 & $86(5.7)$ & $79(4.8)$ & $84(6.1)$ & $83(6.7)$ & 0.005 \\
\hline 25- Bromopropylate & 39.71 & 0.10 & $75(4.3)$ & $77(5.1)$ & $81(4.4)$ & $80(3.9)$ & 0.002 \\
\hline 26- Metoxychlor & 41.29 & 0.06 & $81(4.6)$ & $77(7.3)$ & $82(6.2)$ & $83(4.9)$ & 0.003 \\
\hline 27- Tetradifon & 42.20 & 0.05 & $82(5.1)$ & $79(5.8)$ & $84(4.8)$ & $82(5.9)$ & 0.001 \\
\hline 28- Prochloraz & 45.64 & 0.06 & $82(5.7)$ & $83(6.9)$ & $84(6.6)$ & $82(5.3)$ & 0.005 \\
\hline 29- Cyfluthrin (I) & 46.08 & 0.06 & $83(6.5)$ & $81(7.3)$ & $84(5.8)$ & $83(6.1)$ & 0.005 \\
\hline 30- Cyfluthrin (II) & 46.34 & & & & & & \\
\hline 31- Cyfluthrin (III) & 46.68 & & & & & & \\
\hline 32- Cypermethrin (I) & 47.67 & 0.05 & $79(5.9)$ & $75(6.9)$ & $76(5.5)$ & $76(7.4)$ & 0.003 \\
\hline 33- Cypermethrin (II) & 48.20 & & & & & & \\
\hline 34- Cypermethrin (III) & 48.36 & & & & & & \\
\hline 35- Quizalofop-ethyl & 49.40 & 0.08 & $80(5.3)$ & $76(8.8)$ & $81(6.1)$ & $81(8.4)$ & 0.007 \\
\hline 36- Fenvalerate (I) & 52.29 & 0.06 & $77(6.8)$ & $78(7.1)$ & $82(7.3)$ & $81(6.5)$ & 0.003 \\
\hline 37- Fenvalerate (II) & 53.51 & 0.06 & $75(6.7)$ & $76(8.2)$ & $80(7.5)$ & $79(7.7)$ & 0.003 \\
\hline
\end{tabular}


stirred with a glass rod until a dry, free flowing mixture was obtained. The sample was extracted with $80 \mathrm{~mL}$ of acetone for $30 \mathrm{~min}$ under constant stirring. The mixture was filtered under vacuum, through a Buchner funnel, fitted with Whatman \# 1 filter paper and the residue washed with 2 portions of $30 \mathrm{~mL}$ acetone. The extracted phases were combined, dehydrated by passing through a filter containing a bed of anhydrous $\mathrm{Na}_{2} \mathrm{SO}_{4}$ and concentrated in a rotary evaporator under reduced pressure at $65^{\circ} \mathrm{C}$, and the sample was dried under a gentle stream of pure nitrogen. The residue was dissolved in $5 \mathrm{~mL}$ of acetone and submitted to clean-up using SPE. SFE was performed by using the SFX-220 extraction system (ISCO, Lincoln, NE, USA), which consists of a SFX-220 extractor, a SFX-200 controller, 100 DX syringe pump, and a siphonated Carbon Dioxide cylinder.

Samples of 2 grams of potato, tomato, apple and lettuce were weighed in a $150 \mathrm{~mL}$ beaker and fortified when required with the pesticides standard solution. After a 15 min equilibrium period, $6 \mathrm{~g}$ of the hydromatrix were added to the beaker and the sample was stirred with a glass rod until a dry, free flowing mixture was obtained. The sample was placed in a stainless steel extraction cell $(5.6 \mathrm{~cm}$ x 1.6 $\mathrm{mm}$ i.d.) in a sandwich fashion, using silanized glass wool at both the bottom and the top of the cell to protect cell seals. Before extraction, when necessary, a modifier (acetone or methanol) was added to the samples, by pipeting a calculated volume in relation to the total volume of the SFE cell, so as to obtain a $10 \% \mathrm{v} / \mathrm{v}$ supercritical fluid volume. The extractions were carried out at a temperature of $70{ }^{\circ} \mathrm{C}$ and tested at different extraction pressures: 19971, 44935 and $69898 \mathrm{kPa}$, using a flow rate of expanded gas of $1.5 \mathrm{~mL} \mathrm{~min}^{-1}$ for $25 \mathrm{~min}$, for $\mathrm{CO}_{2}$ or $\mathrm{CO}_{2}$ modified with $10 \%$ of acetone and methanol. A piece of fused silica capillary tube ( $30 \mathrm{~cm} \times 100 \mu$ i.d.) was attached to the outlet of the extractor as a restrictor and the pesticides were directly collected in an aminopropyl cartridge at 10 ${ }^{\circ} \mathrm{C}$ (clean-up SPE).

\section{Clean-up SPE}

A 12-manifold Supelco VISIPREP was used for the sample clean-up, performed in aminopropyl cartridges.

The aminopropyl cartridges were attached to the vacuum manifold and prepared by loading magnesium sulfate to fill approximately one third of the cartridge volume. The clean-up cartridge (magnesium sulfateaminopropyl cartridge) was conditioned with approximately $5 \mathrm{~mL}$ of 50:50 ethyl acetate/n-hexane. The extract was added to the column and eluted under gravity with two portions of $5 \mathrm{~mL}$ each of acetone/n-hexane, 80:20,
50:50, and ethyl acetate/n-hexane 20:80. Once elution was completed, the collected extracts were concentrated under a gentle $\mathrm{N}_{2}$ stream. The residue was quantitatively dissolved in $1 \mathrm{~mL}$ of acetone and submitted to analysis by GC/ECD and GC/MS.

\section{Recovery study}

The chopped and blended crop sample was fortified in triplicate with each working solution and processed after 15 min (equilibrium time) as described in the extraction procedure. Fortification levels for each pesticide, ranging from 0.04 to $0.10 \mathrm{mg} \mathrm{kg}^{-1}$ are reported in Table 1 .

\section{$G C / E C D$}

A Hewlett Packard Model 5890 Series II gas chromatograph equipped with a ${ }^{63} \mathrm{Ni}$ electron-capture detector and a fused silica capillary column HP-608 (30 m x $0.25 \mathrm{~mm}$ i.d., film thickness $0.25 \mu \mathrm{m}$ ) was used. The operating conditions were as follows: initial temperature $45^{\circ} \mathrm{C}(1 \mathrm{~min})$, increased at $20^{\circ} \mathrm{C} \mathrm{min}{ }^{-1}$ to $150{ }^{\circ} \mathrm{C}$, held for $5 \mathrm{~min}$, then increased at $4{ }^{\circ} \mathrm{C} \mathrm{min}^{-1}$ to $280^{\circ} \mathrm{C}$ for $20 \mathrm{~min}$; injector temperature $250{ }^{\circ} \mathrm{C}$; carrier gas $\mathrm{H}_{2}$; column linear velocity $\left(\mu=45 \mathrm{~cm} \mathrm{~s}^{-1}\right)$; detector temperature $300^{\circ} \mathrm{C}$; makeup gas $\mathrm{N}_{2}$; operated in the splitless mode; purge off time $1 \mathrm{~min}$; injection volume $1 \mu \mathrm{L}$.

\section{GC/MS}

A confirmatory analysis run was done on a Hewlett Packard Model 5890 Series II gas chromatograph with a HP 5972 mass selective detector (quadrupole) and a fused -silica capillary column LM-5- 5\% phenyl 95\% dimethylpolysiloxane ( $35 \mathrm{~m}$ x $0.25 \mathrm{~mm}$ i.d., film thickness $0.25 \mu \mathrm{m})$. GC operated under the following conditions: initial temperature $45^{\circ} \mathrm{C}(1 \mathrm{~min})$, increased at $21^{\circ} \mathrm{C} \mathrm{min}^{-1}$ to $150{ }^{\circ} \mathrm{C}$, held for $5 \mathrm{~min}$, then increased at $4{ }^{\circ} \mathrm{C} \mathrm{min}^{-1}$ to $280{ }^{\circ} \mathrm{C}$, and final temperature being held for $30 \mathrm{~min}$; injector temperature $250^{\circ} \mathrm{C}$; carrier gas He; GC-MS transfer line $280{ }^{\circ} \mathrm{C}$; operated in the splitless mode; purge off time $1 \mathrm{~min}$; injection size $1 \mu \mathrm{L}$. MS conditions: delay solvent $2.9 \mathrm{~min}$; electron impact ionization voltage $70 \mathrm{eV}$; scan rate $1.5 \mathrm{scan} \mathrm{s}^{-1}$; scanned-mass range $40-600 \mathrm{~m} / z$.

\section{Results and Discussion}

\section{Solid-liquid extraction}

In multiresidue monitoring, an important consideration in extraction is the solubility range of the different pesticide 
families as well as the character of the food matrix. An inherent problem with a multiresidue approach is that matrix co-extractives increase as the method includes a wider polarity range of analytes, and no current method is suitable for extracting all pesticides from all matrices. ${ }^{3}$

Owing to is effectiveness for polar and nonpolar pesticides, acetone has been selected as the solvent for the extraction of pesticides from fruit and vegetables. Additional advantages include low toxicity and cost, miscibility in plant materials and ease of evaporation due to its low vapor pressure value. However, the sample extracted with acetone may present a high content of coextractives which can damage the GC capillary column as well as result in a matrix enhancement effect. ${ }^{27}$ Samples which contain more sugars or pigments need further cleanup owing to the relatively large amount of sample injected. Previous experiments showed that weak anion exchangers such as $\mathrm{NH}_{2}$ remove many co-extractives interfering with the GC analysis of pesticides, and are also very efficient in lowering the matrix effects. ${ }^{28,29}$

In a previous work, a multiresidue pesticide analysis method was applied to honey samples demonstrating a good chromatographic separation efficiency for 32 compounds selected from four pesticide classes. ${ }^{30}$ In this work, that analytical methodology was used as a basic method, been adopted to avoid matrix effects due to fruit and vegetables complexity, in order to determine pesticides in such samples. Although no interfering peaks were observed on the chromatograms of the blank extracts obtained under the selected conditions (Figure 1), some matrix peaks were observed when analyzed with ECD, nevertheless, these peaks did not interfere with the selected pesticide analysis, showing to be satisfactory for the studied samples.

High-resolution GC using capillary columns allows us to achieve good separation performances in an adequate time of analysis. Selective and sensitive detectors, such as

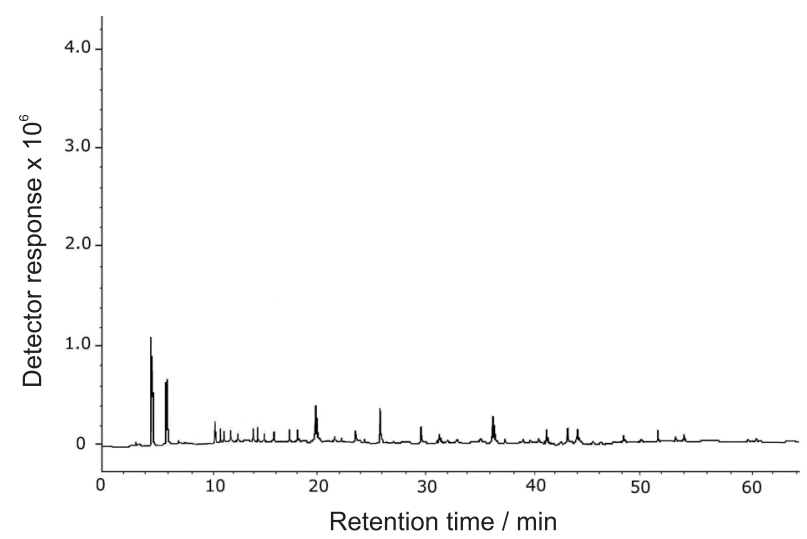

Figure 1. GC-ECD chromatogram of tomato blank extract obtained by the solid-liquid extraction method.
ECD, provided good responses, even in very low concentrations. Optimal chromatographic conditions for the multiresidue analysis of different families of pesticides were studied by comparing the crop sample chromatograms with those obtained from standard mixtures. The concentrations were calculated on the base of peak areas by the external standard method. Retention times of pesticides are listed in Table 1. The results showed that the pesticides eluted separately with the selected column, as well as cyfluthrin, cypermethrin and fenvalerate isomers.

All standard curves were within the acceptable limits of the linearity criterion, with the exception of chlorothalonil, which showed a correlation coefficient of 0.996.

The evaluated method demonstrated an acceptable selectivity for most pesticides analyzed in all the selected matrices.

From the 32 pesticides tested, 29 presented recoveries between $73-85 \%$, which is considered an optimal basis for method validation. Compounds such as dichlorvos, dimethoate and chlorothalonil presented recoveries in the 64-71\% range, which could still be considered acceptable.

Moreover, some compounds presented better recoveries in certain matrices than in others (Table 1). This could probably be due to the phenomenon known as "matrixinduced chromatographic response enhancement".

The detection limits (LOD) were less than $0.01 \mathrm{mg} \mathrm{kg}^{-1}$ for ECD, which is consistent with the legislation minimum detectable quantity. ${ }^{1,25}$ The Relative Standard Deviation (RSD) from 5 to $9 \%$, and the recovery results suggest that the extraction and the clean-up procedure could be considered reliable enough for routine multiresidue screening.

\section{Supercritical Fluid Extraction (SFE)}

Many analytical methods for pesticide analysis in fruit and vegetables involve intensive clean-up procedures which are time-consuming, and require large amounts of toxic solvents, as a norm in traditional liquid solvent. ${ }^{31}$ SFE has become an alternative to traditional organicsolvent based methods, for the removal of analytes from solid matrices.

The high content of water present in samples such as fruit and vegetables, gives rise to restrictor plugging by ice, which carries water into the collection trap. In this work, hydromatrix was used as a drying agent so as to control water.

An optimization study has been carried out using fortified matrices aiming at determining the conditions that would provide maximum recovery in SFE. 


\section{Modifier test}

As shown in Table 2, the solvating power of pure $\mathrm{CO}_{2}$ was too low for exhaustive extraction of the pesticides investigated. Pesticides such as tetradifon, etaconazole, hexaconazole, imazalil, metolachlor, prochloraz, propiconazole, triadimenol, chlorpyrifos, diazinon, dichlorvos and dimethoate were not detected in some matrices or their recovery results ranged from 8 to $26 \%$. However, the best results were obtained for organohalogens, some organonitrogens and pyrethroids with recoveries between 36 and $65 \%$, according to the literature, due to the physicochemical properties of these compounds. ${ }^{31}$

From the results in Table 2, it seems clear that some extraction modification is needed to increase the recovery. To enhance SFE extraction efficiency, $\mathrm{CO}_{2}$ was modified with $10 \%$ acetone and methanol, using samples fortified with target compounds $\left(1 \mathrm{mg} \mathrm{kg}^{-1}\right)$, and clean-up cartridge directly.
As expected, the increase in the addition of the modifier, and consequently the fluid strength, was beneficial for the extraction of most pesticides (Table 2). However, as shown in Table 2, the effect of the modifier in natural matrices is not clear, which means that some pesticides such as bromopropylate, chlorothalonil, endosulfan, tetradifon, buprofezin, metolachlor, dicloran chlorpyrifos, dichlorvos and dimethoate, present maximum recoveries while using acetone, whereas under the same conditions, aldrin, dicofol, hexachlorobenzene, imazalil, trifluralin and diazinon show the presence of co-extractives (recoveries above 140\%). The best result, for the studied samples, was accomplished using $\mathrm{CO}_{2}$ modified with $10 \%$ methanol, presenting recoveries above $50 \%$ and no result of coextractive was observed. This result shows that the addition of $10 \%$ methanol increases the extraction efficiency, improving the solubility of the target analyte or interacting with active sites on the sample matrix, which can help $\mathrm{CO}_{2}$ to efficiently extract the analyte and improve the selectivity

Table 2. Recoveries of pesticides in the matrices studied, using $\mathrm{CO}_{2}$ and $\mathrm{CO}_{2}$ modified with $10 \%$ acetone and $10 \%$ methanol of fortified samples, using direct clean-up with aminopropyl cartridges

\begin{tabular}{|c|c|c|c|c|c|c|c|c|c|c|c|c|}
\hline Pesticides & \multicolumn{4}{|c|}{$\mathrm{CO}_{2}$} & \multicolumn{4}{|c|}{$\mathrm{CO}_{2} 10 \%$ acetone } & \multicolumn{4}{|c|}{$\mathrm{CO}_{2} 10 \%$ methanol } \\
\hline Dichlorvos & 7 & $\mathrm{nd}$ & $\mathrm{nd}$ & 9 & 68 & 70 & 72 & 69 & 62 & 63 & 68 & 65 \\
\hline Linuron & 33 & 35 & 31 & 33 & 66 & 68 & 56 & 59 & 70 & 71 & 66 & 67 \\
\hline Trifluralin & 55 & 58 & 51 & 57 & 260 & 158 & 161 & 251 & 66 & 61 & 65 & 63 \\
\hline Hexachlorobenzene & 64 & 61 & 69 & 59 & 63 & 65 & 187 & 169 & 63 & 61 & 71 & 60 \\
\hline Dicloran & 56 & 54 & 58 & 49 & 72 & 75 & 73 & 72 & 64 & 67 & 65 & 69 \\
\hline Diazinon & nd & $\mathrm{nd}$ & 13 & nd & 55 & 159 & 58 & 57 & 60 & 58 & 65 & 59 \\
\hline Dimethoate & 12 & $\mathrm{nd}$ & 11 & $\mathrm{nd}$ & 71 & 75 & 77 & 70 & 67 & 64 & 68 & 69 \\
\hline Chlorothalonil & 51 & 58 & 52 & 47 & 66 & 67 & 70 & 65 & 60 & 58 & 59 & 56 \\
\hline Vinclozolin & 32 & 30 & 27 & 29 & 51 & 52 & 58 & 50 & 58 & 63 & 67 & 69 \\
\hline Aldrin & 55 & 56 & 51 & 58 & 58 & 146 & 59 & 55 & 65 & 69 & 71 & 70 \\
\hline Metolachlor & 15 & 18 & 20 & nd & 73 & 69 & 71 & 74 & 59 & 64 & 69 & 68 \\
\hline Triadimefon & $\mathrm{nd}$ & 11 & $\mathrm{nd}$ & $\mathrm{nd}$ & 49 & 45 & 42 & 43 & 69 & 65 & 66 & 59 \\
\hline Chlorpyrifos & 22 & 11 & 14 & 18 & 72 & 69 & 73 & 68 & 62 & 65 & 60 & 66 \\
\hline Dicofol & 25 & 29 & 30 & 31 & 154 & 261 & 63 & 158 & 59 & 61 & 62 & 60 \\
\hline Triadimenol & 25 & 22 & 28 & 23 & 36 & 39 & 33 & 34 & 53 & 58 & 57 & 60 \\
\hline Endosulfan Alfa & 53 & 59 & 58 & 64 & 59 & 58 & 60 & 61 & 60 & 61 & 58 & 63 \\
\hline Hexaconazole & 26 & 29 & 28 & 25 & 55 & 58 & 59 & 56 & 63 & 68 & 69 & 66 \\
\hline Imazalil & 10 & $\mathrm{nd}$ & nd & 11 & 258 & 158 & 143 & 131 & 71 & 75 & 73 & 72 \\
\hline Buprofezin & 39 & 42 & 41 & 38 & 66 & 69 & 69 & 70 & 62 & 63 & 67 & 59 \\
\hline Endosulfan Beta & 55 & 52 & 49 & 59 & 58 & 51 & 49 & 60 & 56 & 52 & 53 & 59 \\
\hline Etaconazole & 24 & $\mathrm{nd}$ & 17 & 29 & 56 & 55 & 59 & 61 & 66 & 59 & 69 & 72 \\
\hline Propiconazole & 25 & 26 & 21 & 18 & 55 & 56 & 60 & 62 & 64 & 63 & 69 & 72 \\
\hline Tebuconazole & 48 & 52 & 53 & 47 & 55 & 58 & 54 & 53 & 63 & 64 & 62 & 61 \\
\hline Diclofop-methyl & 33 & 35 & 36 & 38 & 53 & 55 & 49 & 44 & 60 & 52 & 53 & 49 \\
\hline Bromopropylate & 41 & 52 & 47 & 53 & 69 & 71 & 68 & 67 & 61 & 59 & 58 & 52 \\
\hline Metoxychlor & 53 & 51 & 50 & 52 & 52 & 63 & 61 & 59 & 55 & 63 & 64 & 60 \\
\hline Tetradifon & 43 & 52 & 53 & 59 & 63 & 64 & 61 & 62 & 56 & 52 & 54 & 58 \\
\hline Prochloraz & 9 & $\mathrm{nd}$ & 10 & nd & 45 & 44 & 68 & 67 & 59 & 62 & 73 & 74 \\
\hline Cyfluthrin $^{\mathrm{b}}$ & 63 & 61 & 59 & 57 & 77 & 78 & 69 & 58 & 79 & 75 & 73 & 68 \\
\hline Cypermethrin ${ }^{b}$ & 55 & 59 & 54 & 56 & 68 & 65 & 70 & 56 & 69 & 63 & 66 & 69 \\
\hline Quizalofop-ethyl & 52 & 53 & 55 & 56 & 62 & 60 & 61 & 59 & 67 & 66 & 65 & 64 \\
\hline Fenvalerate $^{\mathrm{b}}$ & 61 & 56 & 55 & 58 & 65 & 66 & 61 & 64 & 64 & 71 & 63 & 65 \\
\hline
\end{tabular}

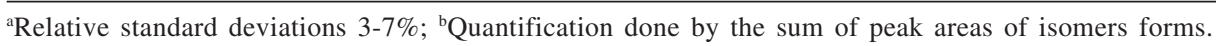


of this method. Based on these results, methanol-modified $\mathrm{CO}_{2}$ was applied in further experiments.

\section{Pressure test}

The choice of pressure and temperature in SFE directly affect selectivity, which is the main advantage over solvents used in solid-liquid extraction methods. The pressure (density) of the extracting fluid is normally of great importance in the determination of the solubility of the analytes in many matrices. ${ }^{32}$ Control of density in SFE has enabled unique applications to separate classes of pesticides from common matrix interference that can plague traditional methods. Nemoto et al. showed the effect of $\mathrm{CO}_{2}$ density for 88 pesticides fortified on celite. ${ }^{33}$ The pesticides were separated into groups (non polar and polar) based on the density required to achieve recoveries above $80 \%$.

Thus, a set of experiments was carried out to check the pressure behavior. The combination of three different pressures (19971, 44935 and $69898 \mathrm{kPa}$ ) using $10 \%$ of methanol as a modifier, was evaluated. These results are summarized in Table 3.

As it can be seen, pressure up to $44935 \mathrm{kPa}$ resulted in increasing recovery results in relation to $19971 \mathrm{kPa}$ (Table 3 ). The recoveries obtained were higher than $81 \%$ for all matrices studied and for $69898 \mathrm{kPa}$ no significant increase in recovery was observed. It is widely believed, by analytical application chemists, that if an analyte is very soluble in supercritical fluid at a low density, this solubility will increase or remain the same at higher densities, or pressures. The combination of both effects of modifiers and pressures lead to the best results in the multiresidue pesticide analysis in fruit and vegetables, as shown in Figures 2 and 3. Accuracy was determined by consecutively analyzing five replicate samples, the standard deviations ranging from 3 to $9 \%$. The recovery results suggest that the SFE procedure could be considered reliable enough for routine multiresidue screening of 32 pesticides in fruit and vegetables samples.

Table 3. Recoveries of pesticides in matrices studied using $\mathrm{CO}_{2}$ modified with $10 \%$ methanol of fortified samples using direct clean-up with aminopropyl cartridges in different pressures and temperature of $70{ }^{\circ} \mathrm{C}$

\begin{tabular}{|c|c|c|c|c|c|c|c|c|c|c|c|c|}
\hline Pesticides & Apple & $\begin{array}{c}19971 \\
\text { Lettuce }\end{array}$ & $\begin{array}{l}\mathrm{kPa}^{\mathrm{a}} \\
\text { Potato }\end{array}$ & Tomato & Apple & $\begin{array}{c}44935 \\
\text { Lettuce }\end{array}$ & $\begin{array}{l}\mathrm{kPa}^{\mathrm{a}} \\
\text { Potato }\end{array}$ & Tomato & Apple & $\begin{array}{r}69898 \\
\text { Lettuce }\end{array}$ & $\begin{array}{l}\mathrm{kPa}^{\mathrm{a}} \\
\text { Potato }\end{array}$ & Tomato \\
\hline Dichlorvos & 62 & 63 & 68 & 65 & 89 & 88 & 87 & 85 & 91 & 89 & 86 & 85 \\
\hline Linuron & 70 & 71 & 66 & 67 & 89 & 91 & 90 & 93 & 85 & 89 & 92 & 94 \\
\hline Trifluralin & 66 & 61 & 65 & 63 & 91 & 90 & 90 & 93 & 90 & 92 & 89 & 91 \\
\hline Hexachlorobenzene & 63 & 61 & 71 & 60 & 93 & 91 & 89 & 92 & 92 & 89 & 90 & 91 \\
\hline Dicloran & 64 & 67 & 65 & 69 & 86 & 89 & 83 & 87 & 83 & 88 & 85 & 86 \\
\hline Diazinon & 60 & 58 & 65 & 59 & 95 & 92 & 91 & 96 & 94 & 93 & 94 & 93 \\
\hline Dimethoate & 67 & 64 & 68 & 69 & 86 & 82 & 84 & 84 & 89 & 84 & 87 & 82 \\
\hline Chlorothalonil & 60 & 58 & 59 & 56 & 94 & 92 & 90 & 95 & 93 & 90 & 88 & 89 \\
\hline Vinclozolin & 58 & 63 & 67 & 69 & 93 & 92 & 89 & 95 & 91 & 89 & 90 & 96 \\
\hline Aldrin & 65 & 69 & 71 & 70 & 91 & 89 & 88 & 90 & 92 & 89 & 93 & 88 \\
\hline Metolachlor & 59 & 64 & 69 & 68 & 96 & 93 & 91 & 94 & 91 & 90 & 91 & 89 \\
\hline Triadimefon & 69 & 65 & 66 & 59 & 85 & 86 & 83 & 89 & 91 & 88 & 92 & 90 \\
\hline Chlorpyrifos & 62 & 65 & 60 & 66 & 89 & 87 & 93 & 94 & 90 & 88 & 92 & 95 \\
\hline Dicofol & 59 & 61 & 62 & 60 & 87 & 82 & 84 & 88 & 88 & 85 & 89 & 92 \\
\hline Triadimenol & 53 & 58 & 57 & 60 & 88 & 90 & 91 & 89 & 89 & 87 & 88 & 88 \\
\hline Endosulfan Alfa & 60 & 61 & 58 & 63 & 92 & 91 & 89 & 90 & 91 & 89 & 88 & 94 \\
\hline Hexaconazole & 63 & 68 & 69 & 66 & 86 & 91 & 90 & 93 & 90 & 90 & 88 & 91 \\
\hline Imazalil & 71 & 75 & 73 & 72 & 82 & 83 & 88 & 86 & 86 & 82 & 87 & 84 \\
\hline Buprofezin & 62 & 63 & 67 & 59 & 88 & 86 & 87 & 85 & 89 & 85 & 84 & 88 \\
\hline Endosulfan Beta & 56 & 52 & 53 & 59 & 90 & 88 & 85 & 91 & 91 & 87 & 86 & 89 \\
\hline Etaconazole & 66 & 59 & 69 & 72 & 92 & 88 & 89 & 91 & 91 & 89 & 85 & 92 \\
\hline Propiconazole & 64 & 63 & 69 & 72 & 88 & 85 & 82 & 86 & 90 & 86 & 87 & 88 \\
\hline Tebuconazole & 63 & 64 & 62 & 61 & 85 & 82 & 85 & 93 & 84 & 81 & 86 & 89 \\
\hline Diclofop-methyl & 60 & 52 & 53 & 49 & 85 & 88 & 91 & 93 & 83 & 92 & 89 & 93 \\
\hline Bromopropylate & 61 & 59 & 58 & 52 & 93 & 88 & 93 & 92 & 90 & 93 & 89 & 91 \\
\hline Metoxychlor & 55 & 63 & 64 & 60 & 87 & 88 & 86 & 89 & 85 & 90 & 87 & 89 \\
\hline Tetradifon & 56 & 52 & 54 & 58 & 91 & 92 & 93 & 95 & 93 & 94 & 90 & 96 \\
\hline Prochloraz & 59 & 62 & 73 & 74 & 89 & 91 & 87 & 84 & 88 & 89 & 91 & 87 \\
\hline Cyfluthrin ${ }^{\mathrm{b}}$ & 79 & 75 & 73 & 68 & 89 & 87 & 89 & 91 & 91 & 86 & 85 & 90 \\
\hline Cypermethrin ${ }^{\mathrm{b}}$ & 69 & 63 & 66 & 69 & 90 & 85 & 86 & 92 & 89 & 87 & 85 & 90 \\
\hline Quizalofop-ethyl & 67 & 66 & 65 & 64 & 87 & 91 & 85 & 90 & 85 & 89 & 86 & 91 \\
\hline Fenvalerate $^{b}$ & 64 & 71 & 63 & 65 & 86 & 89 & 90 & 89 & 88 & 84 & 87 & 91 \\
\hline
\end{tabular}

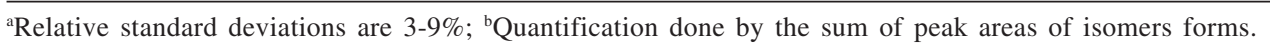




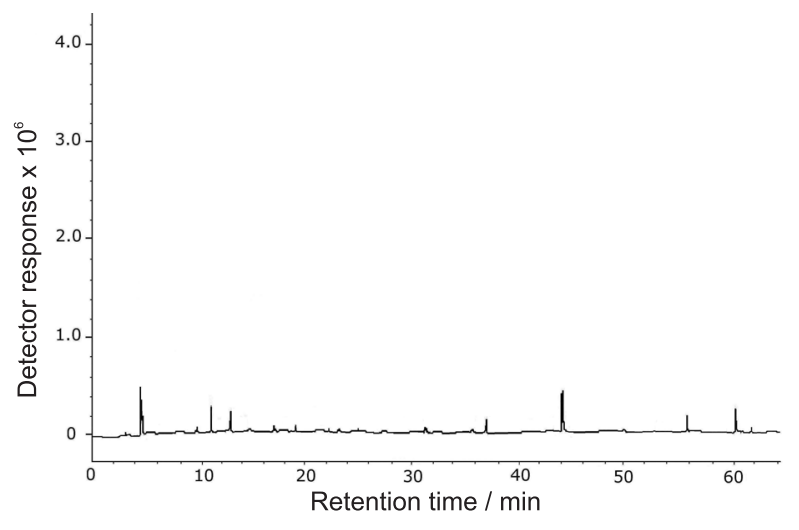

Figure 2. GC-ECD chromatogram of apple blank extract obtained by the supercritical fluid extraction (SFE) method.

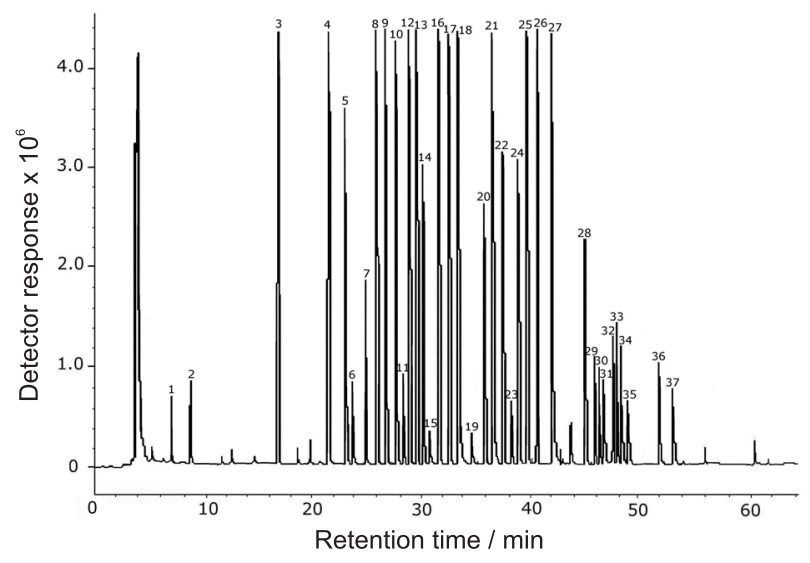

Figure 3. GC-ECD chromatogram of apple fortified extract obtained by the supercritical fluid extraction (SFE) method; pesticides identification correspond to Table 1 .

\section{Application of the developed methods}

Firstly, the identification of the compounds was performed by ECD, comparing the retention times of the standards and the peaks. Peak confirmation is necessary because the chromatograms of real samples can present peaks corresponding to other contaminants or endogenous compounds which elute at the same retention times as the compounds studied. In order to confirm the pesticide identification, MS, in the SIM fashion was used, as reported in Table 4.

The screening results for multiresidue determination by both methods (solid-liquid extraction and SFE) were used to analyze fruit and vegetables from local supermarkets, which are summarized in Table 5. The results showed that $40 \%$ of the analyzed samples gave positive values (higher than routine quantification limits). Only $10 \%$ of them were above the levels established by the Anvisa. ${ }^{34}$ Diazinon, chlorothalonil, tebuconazole and prochloraz were the pesticides most frequently found above
MRL (maximum residue limit). This relatively low number of samples rejected by their consumption owes to the proper usage of pesticides in agricultural matrices, in the studied area. The application of multiresidue methodology using SFE for one real apple sample, for example, is shown in Figure 4.

Table 4. Main ions and relative abundance of pesticides detected by GC/MS

\begin{tabular}{ll}
\hline Pesticides & $\begin{array}{c}\text { Main ions, } m / z \\
\text { (relative abundance\%) }\end{array}$ \\
\hline Dichlorvos & $109(100) ; 185(35) ; 220(9)$ \\
Linuron & $61(100) ; 160(18) ; 248(15)$ \\
Trifluralin & $263(74) ; 306(100) ; 335(10)$ \\
Hexachlorobenzene & $214(22) ; 249(24) ; 284(100)$ \\
Dicloran & $124(100), 176(90), 206(80)$ \\
Diazinon & $88(100) ; 179(71) ; 304(38)$ \\
Dimethoate & $87(100) ; 125(55) ; 229(12)$ \\
Chlorothalonil & $263(70), 293(28), 329(9)$ \\
Vinclozolin & $187(100) ; 212(99) ; 285(75)$ \\
Aldrin & $263(71) ; 293(25) ; 329(9)$ \\
Metolachlor & $162(100) ; 211(12) ; 238(52)$ \\
Triadimefon & $57(100) ; 208(44) ; 293(5)$ \\
Chlorpyrifos & $97(100) ; 197(78) ; 314(46)$ \\
Dicofol & $111(41) ; 139(12) ; 251(72)$ \\
Triadimenol & $112(100) ; 128(45) ; 168(59)$ \\
Endosulfan alfa & $237(100) ; 265(63) ; 339(28)$ \\
Hexaconazole & $83(100) ; 214(45), 231(20)$ \\
Imazalil & $173(96) ; 215(100) ; 296(10)$ \\
Buprofezin & $105(100) ; 172(35) ; 305(18)$ \\
Endosulfan beta & $237(100) ; 265(63) ; 339(28)$ \\
Etaconazole & $173(100) ; 191(35) ; 245(63)$ \\
Propiconazole & $173(100) ; 221(58) ; 259(58)$ \\
Tebuconazole & $125(84) ; 250(100) ; 307(10)$ \\
Diclofop-methyl & $253(100) ; 281(44) ; 340(80)$ \\
Bromopropylate & $149(100) ; 167(25) ; 279(18)$ \\
Metoxychlor & $227(100) ; 274(8) ; 374(3)$ \\
Tetradifon & $159(100) ; 229(55) ; 356(38)$ \\
Prochloraz & $180(100) ; 266(26) ; 308(91)$ \\
Cyfluthrin (I, II, III) & $163(100) ; 206(80) ; 226(51)$ \\
Cypermethrin (I, II, III) & $163(100), 181(86) ; 209(27)$ \\
Quizalofop-ethyl & $243(39) ; 299(100) ; 372(96)$ \\
Fenvalerate (I, II) & $125(100), 167(84), 419(19)$ \\
\hline & \\
& \\
&
\end{tabular}

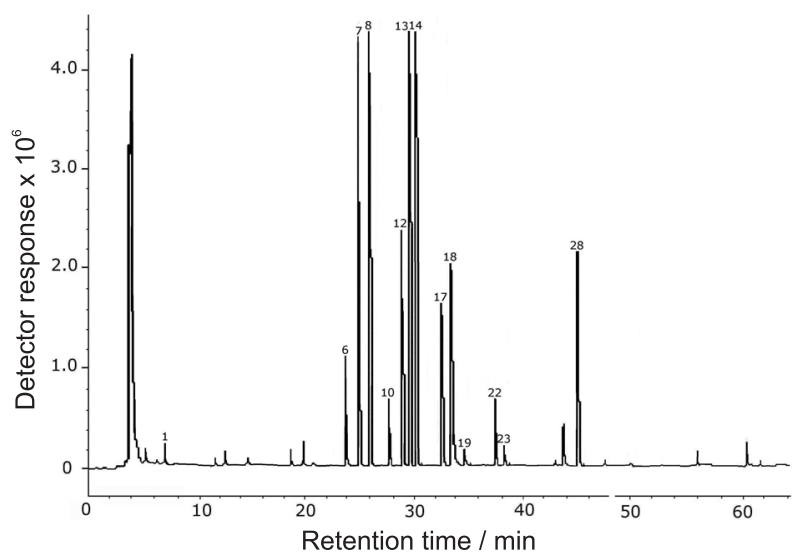

Figure 4. GC-ECD chromatogram of real apple sample obtained by the supercritical fluid extraction (SFE) method, pesticides identification correspond to Table 1. 
Table 5. Pesticide residue $\left(\mathrm{mg} \mathrm{kg}^{-1}\right)$ determined in real samples by the solid-liquid and SFE methods

\begin{tabular}{|c|c|c|c|c|c|c|c|c|}
\hline \multirow[t]{2}{*}{ Pesticides } & \multicolumn{4}{|c|}{ Solid liquid extraction a } & \multicolumn{4}{|c|}{ Supercritical fluid extraction ${ }^{a}$} \\
\hline & Apple & Lettuce & Potato & Tomato & Apple & Lettuce & Potato & Tomato \\
\hline Dichlorvos & $\mathrm{nd}$ & nd & $\mathrm{nd}$ & nd & 0.098 & nd & $\mathrm{nd}$ & nd \\
\hline Linuron & nd & 0.651 & 0.570 & $\mathrm{nd}$ & $\mathrm{nd}$ & 0.773 & 0.582 & nd \\
\hline Trifluralin & nd & 0.045 & $\mathrm{nd}$ & 0.038 & $\mathrm{nd}$ & 0.061 & $\mathrm{nd}$ & 0.059 \\
\hline Hexachlorobenzene & nd & nd & nd & $\mathrm{nd}$ & $\mathrm{nd}$ & nd & $\mathrm{nd}$ & nd \\
\hline Dicloran & nd & nd & 0.129 & nd & $\mathrm{nd}$ & nd & 0.151 & nd \\
\hline Diazinon & 0.508 & nd & $\mathrm{nd}$ & nd & 0.534 & nd & $\mathrm{nd}$ & nd \\
\hline Dimethoate & 0.734 & nd & nd & 0.896 & 0.911 & nd & $\mathrm{nd}$ & 0.887 \\
\hline Chlorothalonil & $\mathrm{nd}$ & 0.009 & 0.092 & 0.884 & $\mathrm{nd}$ & 0.012 & 0.098 & 0.925 \\
\hline Vinclozolin & $\mathrm{nd}$ & $\mathrm{nd}$ & $\mathrm{nd}$ & $\mathrm{nd}$ & $\mathrm{nd}$ & $\mathrm{nd}$ & $\mathrm{nd}$ & $\mathrm{nd}$ \\
\hline Aldrin & $\mathrm{nd}$ & 0.003 & nd & 0.003 & 0.002 & 0.003 & $\mathrm{nd}$ & 0.004 \\
\hline Metolachlor & $\mathrm{nd}$ & $\mathrm{nd}$ & nd & $\mathrm{nd}$ & $\mathrm{nd}$ & $\mathrm{nd}$ & $\mathrm{nd}$ & $\mathrm{nd}$ \\
\hline Triadimefon & 0.144 & nd & nd & 0.193 & 0.158 & nd & nd & 0.336 \\
\hline Chlorpyrifos & 1.137 & 0.921 & 0.840 & 0.665 & 1.249 & 1.337 & 1.506 & 0.949 \\
\hline Dicofol & 3.604 & $\mathrm{nd}$ & $\mathrm{nd}$ & $\mathrm{nd}$ & 3.755 & $\mathrm{nd}$ & $\mathrm{nd}$ & $\mathrm{nd}$ \\
\hline Triadimenol & $\mathrm{nd}$ & $\mathrm{nd}$ & nd & 0.058 & $\mathrm{nd}$ & nd & $\mathrm{nd}$ & 0.066 \\
\hline Endosulfan alfa & $\mathrm{nd}$ & nd & 0.002 & $\mathrm{nd}$ & $\mathrm{nd}$ & nd & 0.002 & $\mathrm{nd}$ \\
\hline Hexaconazole & 0.096 & nd & $\mathrm{nd}$ & 0.087 & 0.144 & nd & $\mathrm{nd}$ & 0.082 \\
\hline Imazalil & nd & nd & 0.084 & $\mathrm{nd}$ & 0.097 & nd & 0.102 & nd \\
\hline Buprofezin & 0.092 & nd & $\mathrm{nd}$ & 0.378 & 0.088 & $\mathrm{nd}$ & nd & 0.090 \\
\hline Endosulfan beta & $\mathrm{nd}$ & nd & nd & $\mathrm{nd}$ & $\mathrm{nd}$ & nd & $\mathrm{nd}$ & 0.002 \\
\hline Etaconazole & $\mathrm{nd}$ & nd & nd & nd & $\mathrm{nd}$ & nd & 0.024 & nd \\
\hline Propiconazole & $\mathrm{nd}$ & $\mathrm{nd}$ & nd & 0.024 & $\mathrm{nd}$ & $\mathrm{nd}$ & $\mathrm{nd}$ & 0.027 \\
\hline Tebuconazole & 0.083 & 0.094 & 0.013 & 0.011 & 0.122 & 0.097 & 0.012 & 0.013 \\
\hline Diclofop-methyl & nd & nd & $\mathrm{nd}$ & 0.007 & nd & nd & nd & 0.008 \\
\hline Bromopropylate & $\mathrm{nd}$ & nd & $\mathrm{nd}$ & 0.005 & 0.002 & nd & $\mathrm{nd}$ & 0.005 \\
\hline Metoxychlor & $\mathrm{nd}$ & $\mathrm{nd}$ & 0.005 & $\mathrm{nd}$ & $\mathrm{nd}$ & $\mathrm{nd}$ & 0.004 & $\mathrm{nd}$ \\
\hline Tetradifon & $\mathrm{nd}$ & 0.432 & $\mathrm{nd}$ & 0.533 & $\mathrm{nd}$ & 0.489 & $\mathrm{nd}$ & 0.579 \\
\hline Prochloraz & 0.355 & 0.128 & $\mathrm{nd}$ & 0.472 & 0.373 & 0.129 & nd & 0.488 \\
\hline Cyfluthrin $^{\mathrm{b}}$ & $\mathrm{nd}$ & $\mathrm{nd}$ & nd & $\mathrm{nd}$ & $\mathrm{nd}$ & $\mathrm{nd}$ & $\mathrm{nd}$ & $\mathrm{nd}$ \\
\hline Cypermethrin ${ }^{\mathrm{b}}$ & $\mathrm{nd}$ & 0.038 & 0.022 & $\mathrm{nd}$ & nd & 0.039 & 0.046 & 0.091 \\
\hline Quizalofop-ethyl & $\mathrm{nd}$ & 0.025 & 0.031 & 0.029 & $\mathrm{nd}$ & 0.024 & 0.030 & 0.033 \\
\hline Fenvalerate $^{\mathrm{b}}$ & $\mathrm{nd}$ & nd & $\mathrm{nd}$ & $\mathrm{nd}$ & $\mathrm{nd}$ & $\mathrm{nd}$ & $\mathrm{nd}$ & nd \\
\hline
\end{tabular}

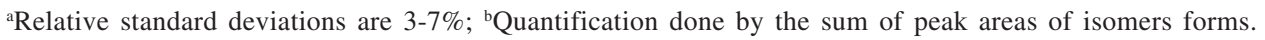

Fungicide residues were those most frequently found and this fact may be explained by their large application for post-harvest protection. An organohalogen, two organonitrogens and an organophosphorus: chlorothalonil, prochloraz, tebuconazole and chlorpyrifos, respectively, were most abundant and, in many instances, the latter exceeded the legislative limits. In some cases, residues such as aldrin were found in illegally sprayed crops of tomato and lettuce.

As one can see, the main differences within the methods were found for imazalil, tebuconazole, triadimefon, chlorpyrifos and cypermethrin, which at times were not determined in some matrices by the solid-liquid method, but determined through SFE. In addition, in some cases, the residues found by SFE were higher than those obtained by the solid-liquid method. Some works have demonstrated that classical or conventional methods of extraction for certain pesticides and or metabolites often do not always remove all of the residues from soil, plants, and food products. ${ }^{35,36}$ Therefore, it is likely that in routine pesticide residue monitoring programs, the total pesticide residues in various matrices have been underestimated. Hence, SFE may prove useful in the extraction of these non-extractable residues, often referred to as "bound residues". SFE presents the greatest ability to change solvent conditions by controlling simple parameters (polarity, temperature and pressure) and may be most potential for selectively extracting mobile or bound residue from fruit and vegetable.

Furthermore, SFE simplifies the sample preparation step for the analysis of pesticide multiresidues, providing advantages such as a reduced use of organic solvents, shorter extraction time, smaller sample size and providing a higher extraction power, that is, cutting costs.

\section{Conclusions}

SFE showed to be a successful analytical technique in the multiresidue pesticide analysis, in the extraction of organohalogen, organonitrogen, organophosophorus 
pyrethroid in fruit and vegetables. This method presented advantages over the conventional solvent extraction methods, including reduction in organic solvent consumption, faster analysis time, being potentially more efficient and selective in complex matrices extractions.

SFE is an alternative to solvent-intensive isolation procedures, due to its ability to change solvent conditions and by controlling polarity, temperature and pressure it may present the most potential for extracting mobile or bound residues

With the development of multiresidue methods, 32 pesticides were analyzed in fruit and vegetables. The SFE methodology showed to be efficient and sensitive for all matrices studied, and it can be easily modified to accommodate more compounds. The utilization of mass spectrometric detection provided both information and confirmation of pesticide residues in crops. This proposed method could be incorporated to the routine analysis of fruit and vegetables obtained from local markets in Brazil or any other country.

\section{References}

1. FAO/OMS; Codex Alimentarius - Residuos de Plaguicidas em los Alimentos; Roma, 1994, vol. 2.

2. US Food and Drug Administration, Pesticide Analytical Manual., Multiresidue Methods, $3^{\text {rd }}$, Washington, DC, 1994, vol. 1.

3. Ahmed, F. E.; Trends Anal. Chem. 2001, $20,649$.

4. Zambonin, C. G.; Quinto, M.; De Vietro, N.; Palmisano, F.; Food Chem. 2004, 86, 269.

5. Salleh, S. H.; Saito, Y.; Jinno, K.; Anal. Chim. Act. 2000, 418, 69.

6. Norman, K.N.T.; Panton, S.H.W.; J. Chromatogr. A 2001, 907, 247.

7. Ner1n, C.; Batlle, R.; Cacho J.; J Chromatogr. A 1998, 795, 117.

8. Stefani, R.; Buzzi, M.; Grazzi, R.; J. Chromatogr. A 1997, 782, 123.

9. Ling, Y. -C.; Teng, H. C-; Cartwright, C.; J. Chromatogr. A 1999, 835,145

10. Lanças, F. M.; Galhiane, M. S.; Rissato, S. R.; Chromatographia 1996, 42, 323.

11. Sun, L.; Lee, H.K.; J. Chromatogr. A 2003, 1014, 165.

12. Yanta, T.; Nomura, A.; Horlmoto, Y.; Gonda, S.; J. Chromatogr. A 1996, 750, 175.

13. Reighard, T. S.; Olesik, S. V.; Anal. Chem. 1997, 69, 566.

14. Motashi, N.; Nagashima, H.; Párkányi, C.; J. Biochem. Biophys. Methods 2000, 43, 313.

15. Lehotay, S. L.; Garcia, A. V.; J. Chromatogr. A 1997, 765, 69.

16. Zuin, V. G.; Yariwake, J.H.; Bicchi, C.; J. Chromatogr. A 2003, 985, 159.
17. Lanças, F. M.; Galhiane, M. S.; Rissato, S. R.; Barbirato, M. A.; J. High Resol. Chromatogr. 1997, 20, 369.

18. Chuang, J. C.; Hart, K.; Chang, J. S.; Boman, L. E.; Van Emon, J. M.; Reed, A. W.; Anal. Chim. Acta 2003, 444, 87.

19. Goto, T.; Ito Y.; Oka, H.; Saito, I.; Matsumoto, H.; Nakazawa, H.; Anal. Chim. Acta 2003, 487, 201.

20. Muccio, A. D.; Dommarco, R.; Barbini, D. A.; Santilio, A.; Girolimetti, S.; Ausili, A.; Ventriglia, M.; Generali, T.; Vergoni, L.; J. Chromatogr. A 1993, 643, 363.

21. Navarro, M.; Picó, Y.; Marin, R.; Mañes, J.; J. Chromatogr. A 2001, 968, 201.

22. Štajnbaher, D.; Zupanšiš-KraljE, L.; J. Chromatogr. A 2003 , 1015, 185.

23. Sannino, A.; Bolzoni, L.; Bandini, M.; J Chromatogr. A 2004, 1036, 161.

24. Blasco, C.; Fernandez, M.; Pena, A.; Lino, C.; Silveira ,M. I.; Font, G.; Pico, Y.; J Agric. Food Chem. 2003, 51, 8132.

25. Council Directive 90/642/EEC of 27 November 1990 on the fixing of maximum levels for pesticides residues in and on fruit and vegetables; Official Journal of the European Communities L350; European Community: Brussels, 1990, p.71.

26. Adou, K; Bontoyan,W.R.; Sweeney, P.J.; J. Agric. Food Chem. 2001, 49, 4153.

27. Hajšlová, J.; Holadová, K.; Kocourek, V.; Poustka, J.; Godula, M.; Cuhra, P.; Kempný, M.; J. Chromatogr. A 1998, 800, 283.

28. Anastassiades, A.; Lehotay, S. J.; Stajnbaher, D.; Schenck, F. J.; J. Assoc. Off. Anal. Chem. 2003, 86, 412.

29. Fillion, J.; Sauvé, F.; Selwyn, J.; J. Assoc. Off. Anal. Chem. 2000, 83, 698.

30. Rissato, S. R.; Galhiane, M. S.; Knoll, F. R. N.; Apon, B. M.; J. Chromatogr. A 2004, 1048, 153.

31. Lehotay, S.J.; J. Chromatogr. A 1997, 785, 289.

32. Hornsby, A. G.; Wauchope, R. D.; Herner, A. E.; Pesticide Properties in the Environment, Springer-Verlag: New York, NY, 1996.

33. Nemoto, S.; Sasaki, K.; Toyoda, M.; Saito, Y.; J. Chromatogr. Sci. 1997, 35, 467.

34. www.anvisa.gov.br/toxicologia/monografias accessed in December 2004.

35. Huber, R.; Otto, S. In Pesticide Chemistry; Miyamoto, J.; Kearney, P. C., eds.; Pergamon: Oxford, U.K., 1983.

36. Khan, S. U.; Dupont, S. In Pesticide Science and Biotechnology, Sixth IUPAC Congress of Pesticide Chemistry; Greenhalgh, R.; Roberts, T. R., eds.; Blackwell Scientific Publication: Oxford, U.K., 1987.

Received: June 25, 2004

Published on the web: August 9, 2005

FAPESP helped in meeting the publication costs of this article. 